\title{
Historic carbon burial spike in an Amazon floodplain lake linked to riparian deforestation near Santarém, Brazil
}

\author{
Luciana M. Sanders ${ }^{1}$, Kathryn Taffs ${ }^{1}$, Debra Stokes $^{2}$, Christian J. Sanders ${ }^{3}$, Alex Enrich-Prast ${ }^{4,5}$, \\ Leonardo Amora-Nogueira ${ }^{6,7}$, and Humberto Marotta ${ }^{6,7}$ \\ ${ }^{1}$ School of Environment, Science and Engineering, Southern Cross University, Lismore, New South Wales, Australia \\ ${ }^{2}$ Marine Ecology Research Centre, Southern Cross University, P.O. Box 157, Lismore, NSW 2480, Australia \\ ${ }^{3}$ National Marine Science Centre, School of Environment, Science and Engineering, Southern Cross University, \\ Coffs Harbour, New South Wales, Australia \\ ${ }^{4}$ Departamento de Botanica, Universidade Federal do Rio de Janeiro (UFRJ), Rio d Janeiro (RJ), 21941-971, Brazil \\ ${ }^{5}$ Department of Environmental Change, Linköping University, 581 83, Linköping, Sweden \\ ${ }^{6}$ Ecosystems and Global Change Laboratory (LEMG-UFF)/International Laboratory of Global Change (LINCGlobal), \\ Biomass and Water Management Research Center (NAB-UFF), Graduated Program in Geosciences (Environmental \\ Geochemistry), Universidade Federal Fluminense (UFF), Av. Edmundo March, s/n - 24210-310, Niteroi/RJ, Brazil \\ ${ }^{7}$ Sedimentary and Environmental Processes Laboratory (LAPSA-UFF), Department of Geography, Graduated Program in \\ Geography, Universidade Federal Fluminense (UFF), Av. Gal. Milton Tavares de Souza, s/n - 24210-346, Niteroi/RJ, Brazil
}

Correspondence: Luciana M. Sanders (1.sanders.13@student.scu.edu.au)

Received: 20 April 2017 - Discussion started: 17 May 2017

Revised: 21 November 2017 - Accepted: 28 November 2017 - Published: 22 January 2018

\begin{abstract}
Forests along the Amazon Basin produce significant quantities of organic material, a portion of which is deposited in floodplain lakes. Deforestation in the watershed may then have potentially important effects on the carbon fluxes. In this study, a sediment core was extracted from an Amazon floodplain lake to examine the relationship between carbon burial and changing land cover and land use. Historical records from the 1930s and satellite data from the 1970s were used to calculate deforestation rates between 1930 to 1970 and 1970 to 2010 in four zones with different distances from the margins of the lake and its tributaries (100, 500, 1000 and $6000 \mathrm{~m}$ buffers). A sediment accumulation rate of $\sim 4 \mathrm{~mm} \mathrm{yr}^{-1}$ for the previous $\sim 120$ years was determined from the ${ }^{240+239} \mathrm{Pu}$ signatures and the excess ${ }^{210} \mathrm{~Pb}$ method. The carbon burial rates ranged between 85 and $298 \mathrm{~g} \mathrm{C} \mathrm{m}^{-2} \mathrm{yr}^{-1}$, with pulses of high carbon burial in the $1950 \mathrm{~s}$, originating from the forest vegetation as indicated by $\delta^{13} \mathrm{C}$ and $\delta^{15} \mathrm{~N}$ signatures. Our results revealed a potentially important spatial dependence of the organic carbon (OC) burial in Amazon lacustrine sediments in relation to deforestation rates in the catchment. These deforestation rates were more intense in the riparian vegetation $(100 \mathrm{~m}$
\end{abstract}

buffer) during the period 1930 to 1970 and the larger open water areas (500, 1000 and $6000 \mathrm{~m}$ buffer) during 1970 to 2010. The continued removal of vegetation from the interior of the forest was not related to the peak of OC burial in the lake, but only the riparian deforestation which peaked during the 1950s. Therefore, this supports the conservation priority of riparian forests as an important management practice for Amazon flooded areas. Our findings suggest the importance of abrupt and temporary events in which some of the biomass released by deforestation, especially restricted to areas along open water edges, might reach the depositional environments in the floodplain of the Amazon Basin.

\section{Introduction}

Rivers act as vectors, transporting sediment from land to ocean (Cole et al., 2007). Along this trajectory a significant proportion of the sediment load, including organic material, may be deposited in floodplains, creating zones of carbon accumulation (Smith et al., 2002; Dong et al., 2012; Hoffmann et al., 2013). This process is accelerated during flood 


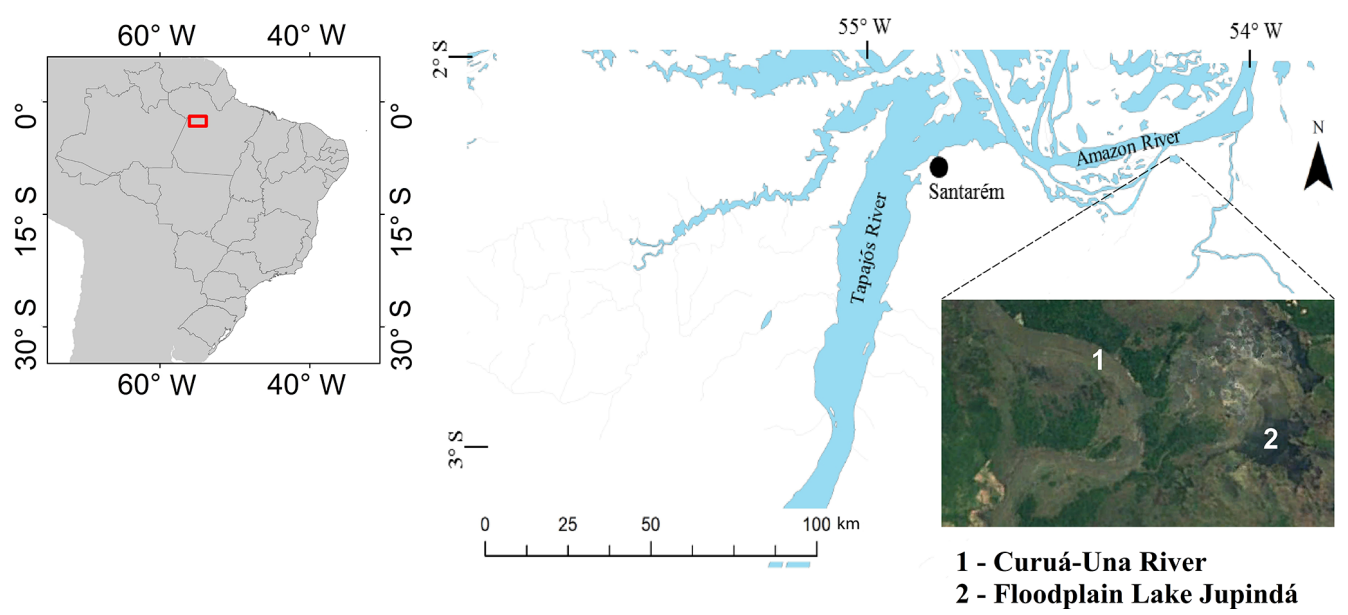

Figure 1. Jupindá Lake where the sediment core was extracted, near the Amazon River and the city of Santarém, Brazil. This floodplain lake has a diameter of approximately $3 \mathrm{~km}$.

events, when rivers and tributaries deposit organic material along the inundated floodplains (Smith et al., 2002). In some climate zones, floodplains are seasonally inundated, with riparian zone vegetation dependent upon this seasonal influx of organic material. The riparian vegetation slows water velocity and traps fine-grained, carbon-rich sediments within this low-energy environment (Aalto et al., 2003). Therefore, the riparian vegetation along the floodplains may be important for the organic matter deposition and the Amazon carbon cycle.

The importance of tropical wetland ecosystems in the carbon cycle is well-documented (Downing et al., 1993; Melack et al., 2004; Zocatelli et al., 2013; Abril et al., 2014; Marotta et al., 2014). It has been shown that wetlands in the warm tropics are some of the most productive biological communities in the world (Neue et al., 1997), representing an important sink for nutrients (Marotta et al., 2009) and carbon (Peixoto et al., 2016; Sanders et al., 2017) as well as sources of organic substrates for carbon gas production in inland waters (Marotta et al., 2010). However, these wetland ecosystems are also highly threatened by land use activities, especially from deforestation, development of agricultural land and soil degradation (Junk, 2013; Lucas et al., 2014).

The Amazon Basin wetlands are being degraded by farming activities such as commercial ranching and an increase in road density (Goulding, 1993). Deforestation of the Amazon Basin commenced around $\sim 1930$ and accelerated towards the end of the 1970s (Skole and Tucker, 1993), when an estimated $15 \%$ of the pristine rainforest area was lost by the year 2003, increasing to approximately $18 \%$ by 2015 (INPE, 2016). The ongoing loss of vegetation is responsible for a substantial increase in erosion rates and subsequent sediment inputs into Amazon rivers and lakes (Neill et al., 2013b). Yet these anthropogenic activities are potential sources of allochthonous organic matter that may increase carbon stores in the associated floodplain areas (Diaz and Rosenberg, 2008; Stanley et al., 2012).

Jupindá Lake, in the state of Pará, provides an ideal opportunity to investigate historical changes in organic carbon (OC) burial in a floodplain lake as a result of the welldocumented anthropogenic activities within its watershed. This will aid in identifying the little-known impacts of land cover changes on recent carbon burial rates in depositional environments of the Amazon floodplain. The objectives of this research are to investigate the effects of deforestation and urban development on carbon burial rates in a tropical floodplain lake. We hypothesize that the historical deforestation in this region of the Amazon may have influenced the OC burial rates in the studied floodplain lake.

\section{Methods}

The city of Santarém, in the center of the Amazon forest, was established in the mid-eighteenth century, approximately $650 \mathrm{~km}$ upstream from the Amazon River mouth and at its confluence with the Tapajós River $\left(02^{\circ} 25^{\prime} 0.28^{\prime \prime} \mathrm{S}\right.$, $54^{\circ} 42^{\prime} 41.57^{\prime \prime} \mathrm{W}$; Fig. 1). In 1940, Santarém was only a small village, less than $0.5 \mathrm{~km}^{2}$, surrounded by dense pristine rainforest (estimated from the historical mapping of the Santarém City Hall). This city quickly expanded, occupying $5.2 \mathrm{~km}^{2}$ by the end of the $1970 \mathrm{~s}$ and $49.3 \mathrm{~km}^{2}$ currently (estimated from satellite images LANDSAT/SRTM). Jupindá Lake is $70 \mathrm{~km}$ east of Santarém city, and receives surface water inflow from small streams draining from the forest and the main tributary Curuá-Una River, a large affluent of the Amazon River (Fig. 1). The lake has been affected by the deforestation associated with the expansion of Santarém city. Between the 1940s and 1950s there was intense deforestation on the margins of rivers and streams in this area, used to supply the markets with wood and forestry products (Amorim, 2000; 


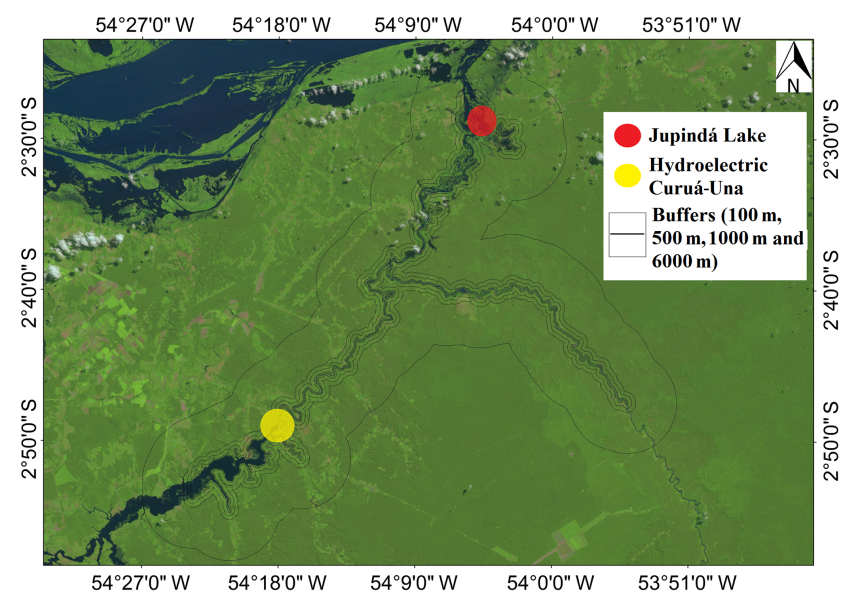

Figure 2. Different buffer sizes (100, 500, 1000 and $6000 \mathrm{~m})$ along the stretch of the Curuá-Una River from Jupindá Lake (red) to the hydroelectric dam upstream (yellow).

Cruz et al., 2011). In the 1970s, the Curuá-Una River was dammed (Curuá-Una Dam) $45 \mathrm{~km}$ upstream of Jupindá Lake to build the first hydroelectric plant of the Amazon rainforest (Ligocki, 2003).

A $60 \mathrm{~cm}$ sediment core (diameter $7.5 \mathrm{~cm}$ ) was collected in 2010 using a gravity corer in the center of Jupindá Lake $\left(02^{\circ} 27^{\prime} 43.60^{\prime \prime} \mathrm{S}, 54^{\circ} 5^{\prime} 1.30^{\prime \prime} \mathrm{W}\right)$. The sediment core was sub sampled at $2 \mathrm{~cm}$ intervals. Dry bulk density (DBD, $\mathrm{g} \mathrm{cm}^{-3}$ ) was determined as the dry sediment weight $(\mathrm{g})$ divided by the initial volume $\left(\mathrm{cm}^{3}\right)$. A homogenized portion was acidified $(10 \% \mathrm{HCl}$ following the procedures outlined in Naidu et al., 2000) to remove carbonate material, then dried and ground to powder for $\mathrm{OC}$, nitrogen $(\mathrm{N}), \delta^{13} \mathrm{C}$ and $\delta^{15} \mathrm{~N}$ analyses using a flash elemental analyzer coupled to a Thermo Fisher Delta V IRMS (isotope ratio mass spectrometer). The $\delta^{15} \mathrm{~N}$ results and the $\mathrm{C} / \mathrm{N}$ ratio results should be interpreted with caution, based on this pre-treatment method, which may be influenced by the composition of the bulk organic matter (Brodie et al., 2011). Working standards were used (glucose, $10.7 \mathrm{ppt}$ and urea, $41.3 \mathrm{ppt}$ ) to calibrate for $\delta^{13} \mathrm{C}$. A pair of standards was measured with every 20 samples. These standards were calibrated initially against international absolute standards LSVEC and NIST8542. Analytical precision: $\mathrm{C}=0.1 \%, \mathrm{~N}=0.1 \%, \delta^{13} \mathrm{C}=0.1 \%$ and $\delta^{15} \mathrm{~N}=0.15 \%$ 。

Samples were prepared for $\mathrm{Pu}$ dating following the method of Ketterer et al. (2004) with modifications to enable larger sample mass to be processed as a result of the likely lower $\mathrm{Pu}$ concentrations in the Southern Hemisphere (Sanders et al., 2016). To obtain a larger mass, sediment intervals were joined and homogenized so the sediment intervals for the ${ }^{240+239} \mathrm{Pu}$ dating was $4 \mathrm{~cm}$ intervals. Sample aliquots ranging from 14 to $29 \mathrm{~g}$ were dry-ashed at $600^{\circ} \mathrm{C}$ for $16 \mathrm{~h}$, and leached with $50 \mathrm{~mL}$ of $16 \mathrm{M} \mathrm{HNO}_{3}$. The leaching was conducted overnight at $80^{\circ} \mathrm{C}$ with added ${ }^{242} \mathrm{Pu}$ yield tracer (NIST 4334g, 19 picograms). Acid leaching (as opposed to complete dissolution with HF) is known to solubilize stratospheric fallout $\mathrm{Pu}$, and there is little possibility that "refractory" $\mathrm{HNO}_{3}$-insoluble Pu exists in South America (Sanders et al., 2014). The leachates were diluted to $100 \mathrm{~mL}$, filtered to remove solids and the aqueous solutions were processed with TEVA $^{\circledR}$ Resin (EIChrom, Lisle, IL, USA) in order to chemically isolate $3.0 \mathrm{~mL} \mathrm{Pu}$ fractions in aqueous ammonium oxalate solution suitable for measurements by sector ICPMS (inductively coupled plasma mass spectrometry). Pu determinations were performed using a VG Axiom MC operating in the single collector (electron multiplier) mode. The system was used with an APEX HF desolvating micronebulizer system (ESI Scientific, Omaha, NE, USA) with an uptake rate of $0.4 \mathrm{~mL} \mathrm{~min}^{-1}$. Qualitative mass spectral scans were collected for selected samples prior to the electrostatic sector quantitative scanning of ${ }^{238} \mathrm{U},{ }^{239} \mathrm{Pu},{ }^{240} \mathrm{Pu}$ and ${ }^{242} \mathrm{Pu}$. Detection limits were evaluated based on the analysis of two blanks and considerations regarding the obtained mass spectra. A detection limit of $0.01 \mathrm{~Bq} \mathrm{~kg}^{-1}$ of ${ }^{239+240} \mathrm{Pu}$ is applicable for samples of nominal $25 \mathrm{~g}$ mass.

For ${ }^{210} \mathrm{~Pb}$ dating, an intrinsic germanium detector coupled to a multi-channel analyzer was used. Freeze dried and ground sediments were packed and sealed in gamma tubes. Lead-210 and ${ }^{226} \mathrm{Ra}$ activities were calculated by multiplying the counts per minute by a factor that includes the gammaray intensity and detector efficiency determined from standard calibrations. Identical geometry was used for all samples. Lead-210 activities were determined by the direct measurement of the $46.5 \mathrm{KeV}$ gamma peak. Radium-226 activity was determined via the ${ }^{214} \mathrm{~Pb}$ daughter at $351.9 \mathrm{KeV}$. For ${ }^{226} \mathrm{Ra}$ measurements, the packed samples were set aside for at least 21 days to allow for ${ }^{222} \mathrm{Rn}$ to ingrow and establish secular equilibrium between ${ }^{226} \mathrm{Ra}$ and its granddaughter ${ }^{214} \mathrm{~Pb}$. Excess ${ }^{210} \mathrm{~Pb}$ activity was calculated by subtracting the supported ${ }^{210} \mathrm{~Pb}$ (i.e., ${ }^{226} \mathrm{Ra}$ activity) from the total ${ }^{210} \mathrm{~Pb}$ activity. The sediment accretion rate for the previous 120 years was estimated by two methods derived from ${ }^{210} \mathrm{~Pb}$ dating: the Constant Initial Concentration (CIC) model assuming that this rate has not varied during the encompassed time span (Appleby and Oldfield, 1992) and the Constant Rate of Supply (CRS) model based on a constant influx of unsupported, atmospheric ${ }^{210} \mathrm{~Pb}$ that allows a variable sediment rate (Ivanovich and Harmon, 1992). OC accumulation rates were estimated from an average between these two dating methods $\left({ }^{239+240} \mathrm{Pu}\right.$ and $\left.{ }^{210} \mathrm{~Pb}_{\mathrm{ex}}\right)$, the DBD $\left(\mathrm{g} \mathrm{cm}^{3}\right)$ and carbon content for each interval of the entire sediment core.

The land use and land cover analysis was based on documented historical information before 1975 and satellite images (Landsat/SRTM, Table 1) from 1975, 1985, 1995 and 2008 available from the United States Geological Survey (USGS). No significant deforestation occurred in the catchment area of the Jupindá Lake until the early 1940s (Amorim, 2000; Cruz et al., 2011). Subsequent land use changes were determined using satellite images (Gordon, 1980; Munyati, 2000). All satellite images were from low-water seasons to 


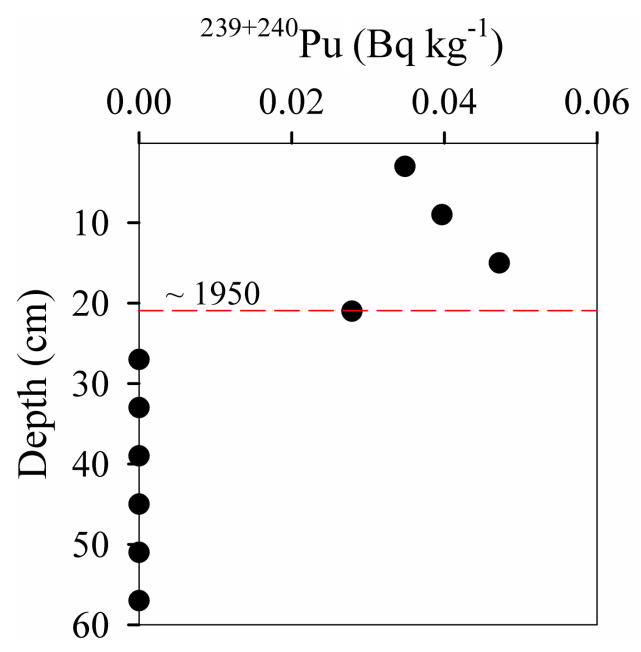

Figure 3. ${ }^{239+240} \mathrm{Pu}$ profile, indicating that $\sim 1950$ is when these radionuclides were first introduced into the atmosphere.
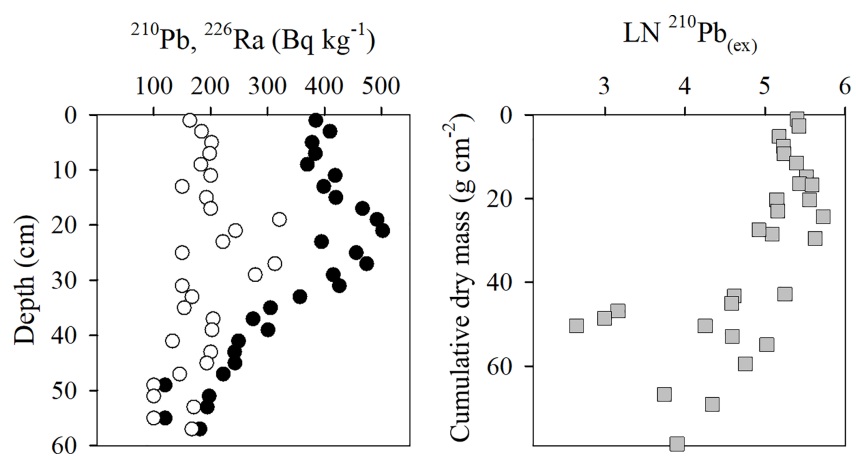

Figure 4. Lead-210 (black circles) and ${ }^{226} \mathrm{Ra}$ (white circles) profiles against depth. Grey squares represent the ${ }^{210} \mathrm{~Pb}_{(\mathrm{ex})}$ profile vs. cumulative dry mass.

remove the influence of the flood pulse on the exposed area over years. The resolution of the images was $30 \mathrm{~m}$, except those from the 1970s, which were resampled from 90 to $30 \mathrm{~m}$ (Table 1). This approach allowed an assessment of changes in land cover to be compared to results from carbon accumulation. Results of the spatial assessment were separated into two time periods: 1930 to 1970 , the time frame between the onset of land clearing and the first satellite image; and 1970 to 2010, which provides a more detailed assessment of temporal changes in the study area. The time period 1930 to 1970 was characterized by a rapid removal (peak until the 1960s) of vegetation established at the margins of inland waters: especially Aniba rosaeodora (Pau-rosa) for extraction of oils, Mezilaurus itauba and Cedrela fissilis (Louro-itaúba and Cedro, respectively) as hardwoods, and the opening of clearings for crops of textile fibers and subsistence products. Intensification of deforestation towards the interior of the forest and following the urban growth of Santarem is reported from the 1970s (Amorim, 2000; Cruz et al., 2011). The depletion of
Table 1. Satellite acquisition data from the United States Geological Survey (USGS) and the Curuá-Una River quota from the Brazilian Water Agency (ANA).

\begin{tabular}{lrr}
\hline Month/year & Landsat data & $\begin{array}{r}\text { Curuá-Una } \\
\text { River quota }\end{array}$ \\
\hline Aug/1975 & 2 & 5.3 \\
Oct/1985 & 5 & 3.7 \\
Jun/1995 & 5 & 6 \\
Jun/2008 & 5 & no data \\
\hline
\end{tabular}

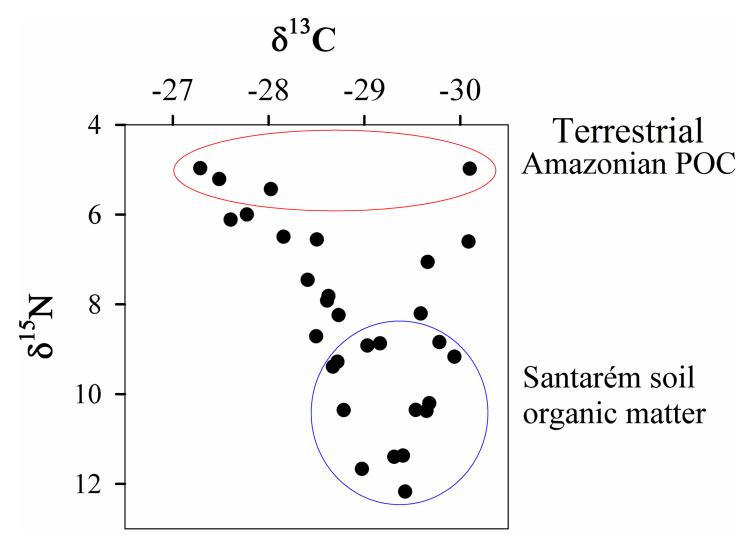

Figure 5. $\delta^{13} \mathrm{C}$ vs. $\delta^{15} \mathrm{~N}$. The Amazon River POC and Santarém soil organic matter values, adjacent to the study area, are taken from Zocatelli et al. (2013).

vegetation near to the margins of lakes and running waters in this region is also well documented (Amorim, 2000; Cruz et al., 2011).

In order to address the spatial dependence of recent OC burial in Jupindá Lake on deforestation, we analyzed the land cover and land use in four buffer areas around the lake and contributing rivers or streams. The first buffer of $100 \mathrm{~m}$ represented the riparian forest area protected by the Brazilian laws for fluvial channels with a width of 50 to $200 \mathrm{~m}$. Other buffers were progressively wider, with a width of 500, 1000 and $6000 \mathrm{~m}$ from the riverbank and lake margins (Fig. 2). In addition, we considered only stretches of rivers and streams $65 \mathrm{~km}$ long from Jupindá Lake to analyze its catchment area of a more direct influence. This criteria also avoids the interference of the artificial flooding on the margins of the CuruáUna hydroelectric dam, which was built in 1977 (Fearnside, 2005).

The statistical treatment of variables and OC burial rates, when grouped into different phases, showed assumptions which required parametric analyses, including normal distribution (Kolmogorov-Smirnov, $p>0.05$ ) and homogeneity of variance (Bartlett, $p>0.05$ ). Thus, we used means and standard errors to represent the distribution of values, and parametric tests were conducted allowing comparison of different phases. Statistical differences were tested using the 


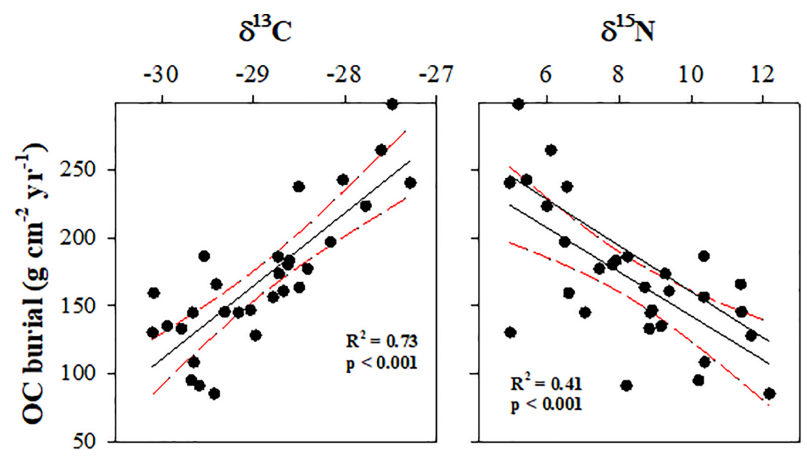

Figure 6. Carbon burial as a function of $\delta^{13} \mathrm{C}$ and $\delta^{15} \mathrm{~N}$.

one-way ANOVA test followed by Tukey's post test (significance was defined as $p<0.05$ ). All the statistical tests used in this work were performed using GraphPad Prism 5.0 software.

\section{Results}

The analyses of ${ }^{239+240} \mathrm{Pu}$ showed no detectable activities from the base of the sediment core until the $22-26 \mathrm{~cm}$ interval (Fig. 3). However, ${ }^{239+240} \mathrm{Pu}$ was detected in the 18 $22 \mathrm{~cm}$ interval $\left(0.029 \pm 0.002 \mathrm{~Bq} \mathrm{~kg}^{-1}{ }^{239+240} \mathrm{Pu}\right)$ with the peak concentration $\left(0.047 \pm 0.004 \mathrm{~Bq} \mathrm{~kg}^{-1} 239+240 \mathrm{Pu}\right)$ at the $16 \mathrm{~cm}$ depth, which indicates the 1963 stratospheric fallout peak. Hence material below $22 \mathrm{~cm}$ was deposited pre-bomb (that is, prior to the early 1950s). This fixes an upper limit on the average sedimentation rate of near to $3.8 \mathrm{~mm} \mathrm{yr}^{-1}$. The $\mathrm{Pu}$ atom ratio data indicate that $\mathrm{Pu}$ is originating from stratospheric fallout with isotopic ratios $\left({ }^{240 / 239} \mathrm{Pu}\right)$ of $\sim$ 0.18 . These results are consistent with the ${ }^{240} \mathrm{Pu} /{ }^{239} \mathrm{Pu}$ of $0.180 \pm 0.014$ discussed by Kelley et al. (1999).

The ${ }^{210} \mathrm{~Pb}$ and ${ }^{226} \mathrm{Ra}$ profiles as well as the ${ }^{210} \mathrm{~Pb}($ ex) profile vs. cumulative dry mass accumulation reveals a complex depositional environment with sedimentation variations and disturbances, such as bioturbation and resuspension in the upper $\sim 20 \mathrm{~cm}$ of the sediment column (Fig. 4). A decrease in ${ }^{210} \mathrm{~Pb}_{\mathrm{ex}}$ activity was found below the $20 \mathrm{~cm}$ depth interval. The ${ }^{210} \mathrm{~Pb}_{\mathrm{ex}}$ data distribution are as follows: $y=$ $-0.0749 x+7.5 ; R^{2}=0.73 ; n=19 ; p<0.01$ from the 20 to the $60 \mathrm{~cm}$ interval, below the apparent mixed zone. Both estimates of sediment accretion rate during the 120 years from the CIC and CRS models were similar, reaching 4.1 and $4.3 \mathrm{~mm} \mathrm{yr}^{-1}$, respectively, which were slightly higher than the $\sim 60$ year ${ }^{239+240} \mathrm{Pu}$ dates $\left(3.8 \mathrm{~mm} \mathrm{yr}^{-1}\right)$. In order to obtain more reliable estimates of the historical carbon burial rates, the ${ }^{239+240} \mathrm{Pu}$ results from around 1950 to present were used $\left(3.8 \mathrm{~mm} \mathrm{yr}^{-1}\right)$ and ${ }^{210} \mathrm{~Pb}_{\mathrm{ex}}\left(4.2 \mathrm{~mm} \mathrm{yr}^{-1}\right)$ was used from $\sim 1890$ to approximately the 1950 s. These rates for each sediment depth were multiplied by the DBD and OC content for each interval of the entire sediment core.
Table 2. Depth profiles of dry bulk density (DBD), total organic carbon (TOC in \%), total nitrogen (TN in \%), carbon and nitrogen $(\mathrm{C} / \mathrm{N})$ molar ratios, $\delta^{13} \mathrm{C}$ and $\delta^{15} \mathrm{~N}$.

\begin{tabular}{|c|c|c|c|c|c|c|}
\hline $\begin{array}{l}\text { Depth } \\
(\mathrm{cm})\end{array}$ & $\begin{array}{r}\text { DBD } \\
\left(\mathrm{g} \mathrm{cm}^{-3}\right)\end{array}$ & $\delta^{15} \mathrm{~N}$ & $\delta^{13} \mathrm{C}$ & $\begin{array}{r}\text { TOC } \\
(\%)\end{array}$ & $\begin{array}{l}\mathrm{TN} \\
(\%)\end{array}$ & $\mathrm{C} / \mathrm{N}$ \\
\hline $0-2$ & 1.0 & 8.9 & -29.2 & 3.8 & 0.3 & 17.2 \\
\hline $2-4$ & 0.9 & 11.7 & -29.0 & 3.8 & 0.3 & 18.7 \\
\hline $4-6$ & 1.0 & 10.4 & -28.8 & 4.0 & 0.3 & 19.2 \\
\hline $6-8$ & 1.1 & 9.3 & -28.7 & 4.3 & 0.3 & 20.2 \\
\hline $8-10$ & 1.0 & 9.4 & -28.7 & 4.1 & 0.3 & 19.8 \\
\hline $10-12$ & 1.1 & 7.9 & -28.6 & 4.6 & 0.3 & 21.2 \\
\hline $12-14$ & 1.1 & 8.2 & -28.7 & 4.3 & 0.3 & 19.9 \\
\hline $14-16$ & 1.1 & 7.8 & -28.6 & 4.3 & 0.3 & 20.9 \\
\hline $16-18$ & 1.0 & 8.7 & -28.5 & 4.4 & 0.3 & 21.2 \\
\hline $18-20$ & 1.1 & 7.5 & -28.4 & 4.4 & 0.3 & 19.8 \\
\hline $20-22$ & 1.0 & 6.5 & -28.2 & 5.4 & 0.3 & 21.2 \\
\hline $22-24$ & 1.0 & 6.0 & -27.8 & 5.3 & 0.3 & 21.5 \\
\hline $24-26$ & 1.0 & 5.2 & -27.4 & 7.3 & 0.4 & 25.4 \\
\hline $26-28$ & 1.1 & 6.1 & -27.6 & 6.0 & 0.3 & 23.8 \\
\hline $28-30$ & 1.0 & 5.0 & -27.3 & 6.0 & 0.4 & 22.7 \\
\hline $30-32$ & 1.0 & 5.4 & -28.0 & 6.1 & 0.3 & 27.0 \\
\hline $32-34$ & 1.3 & 6.6 & -28.5 & 4.4 & 0.2 & 27.5 \\
\hline $34-36$ & 1.6 & 8.9 & -29.0 & 2.2 & 0.1 & 23.1 \\
\hline $36-38$ & 1.4 & 11.4 & -29.4 & 2.9 & 0.1 & 30.4 \\
\hline $38-40$ & 1.4 & 10.4 & -29.5 & 3.3 & 0.1 & 30.5 \\
\hline $40-42$ & 1.5 & 11.4 & -29.3 & 2.4 & 0.1 & 23.8 \\
\hline $42-44$ & 1.6 & 12.2 & -29.4 & 1.3 & 0.1 & 15.6 \\
\hline $44-46$ & 1.8 & 8.2 & -29.6 & 1.2 & 0.1 & 14.3 \\
\hline $46-48$ & 1.5 & 8.8 & -29.8 & 2.2 & 0.1 & 21.6 \\
\hline $48-50$ & 0.9 & 10.4 & -29.7 & 2.9 & 0.2 & 25.6 \\
\hline $50-52$ & 0.9 & 10.2 & -29.7 & 2.6 & 0.1 & 27.2 \\
\hline $52-54$ & 0.9 & 7.1 & -29.7 & 3.9 & 0.2 & 28.6 \\
\hline $54-56$ & 0.9 & 9.2 & -29.9 & 3.6 & 0.2 & 27.8 \\
\hline $56-58$ & 0.9 & 6.6 & -30.1 & 4.3 & 0.2 & 30.1 \\
\hline $58-60$ & 0.9 & 5.0 & -30.1 & 3.5 & 0.2 & 23.1 \\
\hline Average & 1.11 & 8.34 & -28.9 & 4.0 & 0.2 & 23.0 \\
\hline SD & 0.24 & 2.1 & 0.8 & 1.9 & 0.1 & 4.2 \\
\hline
\end{tabular}

The DBD, total organic carbon (TOC in \%), total nitrogen (TN in \%) content as well as the carbon and nitrogen $(\mathrm{C} / \mathrm{N})$ molar ratios along with the $\delta^{13} \mathrm{C}$ and $\delta^{15} \mathrm{~N}$ values showed a decreasing shift towards the center of the sediment core (Table 2). The relationship between $\delta^{13} \mathrm{C}$ and $\delta^{15} \mathrm{~N}$ indicated different origins of $\mathrm{OC}$ in the sediment core (Fig. 5) contributing to the significant relationship between OC burial and $\delta^{13} \mathrm{C}$ (Fig. 6). The significantly greater $\delta^{13} \mathrm{C}$ peak and lower $\delta^{15} \mathrm{~N}$ values coupled to higher OC burial rates were observed in the phase between $\sim 1930$ and 1970 in Jupindá Lake (one-way ANOVA followed by Tukey's post test, $p<0.05$; Fig. 7). The $\delta^{13} \mathrm{C}$ values were greater in the phase between $\sim 1930$ to 1970 in relation to those previous and after, respectively (one-way ANOVA followed by Tukey's post test, $p<0.05$ ). This peak around 1950 also showed $\delta^{15} \mathrm{~N}$ values lower and OC burial rates higher than 

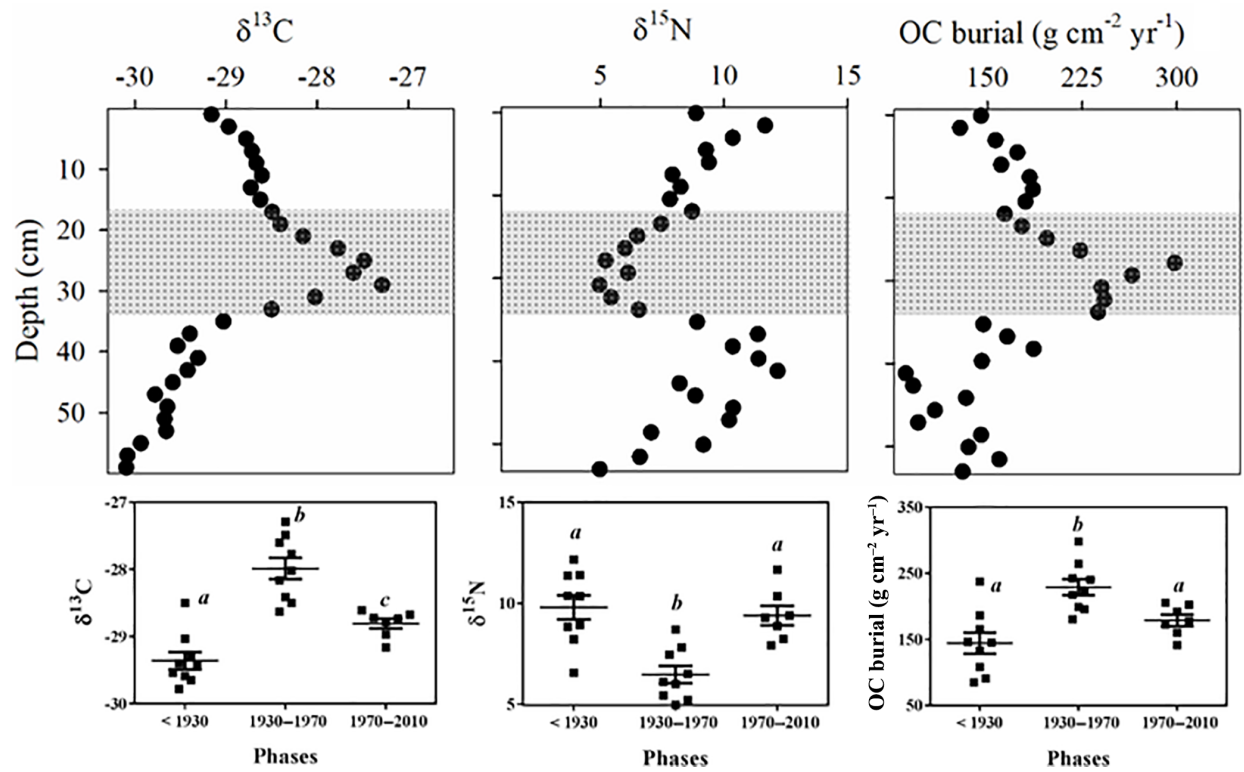

Figure 7. $\delta^{13} \mathrm{C}, \delta^{15} \mathrm{~N}$ and carbon burial rate values in relation to depth (cm). Panels below each vertical profile represent respective data grouped by the three general phases < 1930, 1930-1970 and 1970-2010. Filled square symbols represent means of a given variable in each sediment layer, and the vertical bars show the mean with the SD of the respective phase. Equal letters in each panel represent non-significant differences ( $p>0.05$, one-way ANOVA followed by Tukey's post test).
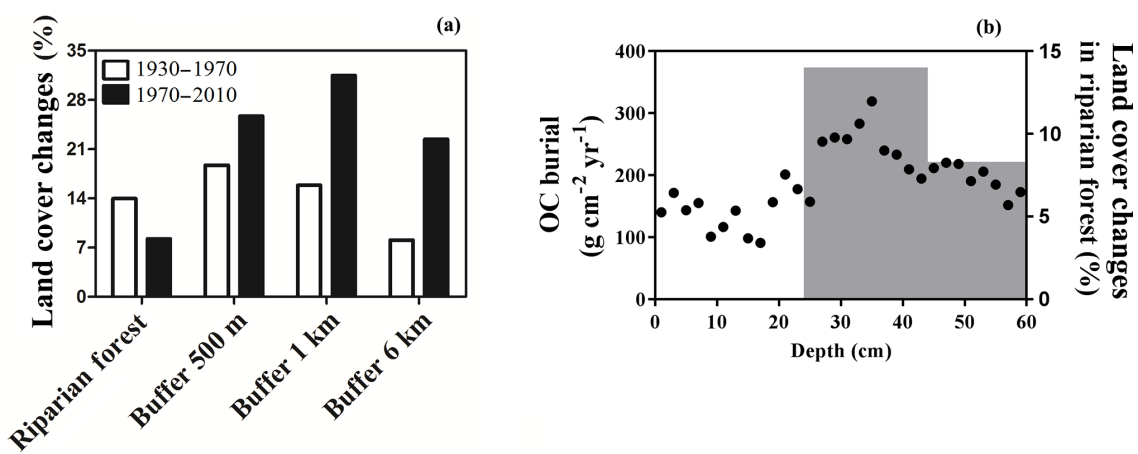

Figure 8. Percentage of modified areas in relation to the different buffers (a). Carbon burial (black dots) and changes in the riparian vegetation (the two grey bars represent the two general phases) as related to time (b).

other phases (one-way ANOVA followed by Tukey's post test, $p<0.05$ ).

The OC burial rates indicate an increasing trend from $\sim 1930$ with a peak during the 1940s and 1950s (Fig. 7). The carbon burial rates increased from $\sim 186 \mathrm{~g} \mathrm{~m}^{-2} \mathrm{yr}^{-1}$ before the 1950s up to $298 \mathrm{~g} \mathrm{~m}^{-2} \mathrm{yr}^{-1}$ between the $1940 \mathrm{~s}$ and 1950s. Carbon accumulation then decreased to approximately $186 \mathrm{~g} \mathrm{~m}^{-2} \mathrm{yr}^{-1}$ from 1960 to 1980 , after which a gradual decline in carbon burial is noted. In relation to land use and cover in the surrounding fluvial channels and the Jupindá Lake, only the smallest buffer $(100 \mathrm{~m})$ showed significant changes during 1930-1970. This time period is when deforestation was nearly $75 \%$ higher than in the subsequent time period 1970-2010 (Fig. 8a) and when OC burial was greatest (Fig. 8b).

\section{Discussion}

Similar estimates of sediment accretion were calculated using different methodologies $\left({ }^{239+240} \mathrm{Pu}\right.$ and $\left.{ }^{210} \mathrm{~Pb}_{(\mathrm{ex})}\right)$. These accretion rates along with the DBD revealed an insight into changes in the sediment sources of floodplains, and their relationships with changing land cover and land use in the Amazon Basin. The Jupindá Lake showed substantial changes in the carbon burial rates following deforestation, supporting the connection between flooded areas and their surrounding vegetation. The high peak in carbon accumulation observed around 1950 appears to be associated with a shift in the source of organic material, inferred by changes in carbon and nitrogen contents and the isotopic fractioning towards the middle (from 20 to $40 \mathrm{~cm}$ depth interval) of the sediment 
column. This peak for different organic and inorganic variables in intermediate depths revealed changes not only in the amount but also in the type of material being deposited over time. Previous studies have reported two common origins for $\mathrm{OC}$ in the Amazon forest. Higher $\delta^{15} \mathrm{~N}$ and more negative $\delta^{13} \mathrm{C}$ values could indicate the presence of Santarém soil organic matter (such as that adjacent to the Jupindá Lake), while lower $\delta^{15} \mathrm{~N}$ and more variable $\delta^{13} \mathrm{C}$ values indicate particulate organic carbon (POC) from the terrestrial vegetation in the catchment (Ometto et al., 2006; Zocatelli et al., 2013). Here, a corresponding increase in TOC, TN and OC burial rates measured, with a peak around 1950, suggesting higher inputs of organic matter into the lake. The higher $\delta^{13} \mathrm{C}$ signature, coupled with a lower $\delta^{15} \mathrm{~N}$, indicates a greater influence from the terrestrial Amazonian POC during the same period, around 1950 (Ometto et al., 2006).

When looking for a cause for this change in the source of organic material, we look to the analysis of land use change. Land clearing associated with early occupation from the 1940s in the catchment area of the Jupindá Lake may be a potential cause of the increased carbon burial observed in the lake. Changes in land use and associated deforestation may significantly affect $\mathrm{OC}$ burial in mid- to high-latitude lakes (Anderson et al., 2013; Dietz et al., 2015). Indeed, our results suggest that land clearing during the 1940s and 1950s might be related to increased organic matter deposition in the region's floodplain lakes. During this period, intense wood extraction and expansion of agricultural settlements occurred (Amorim, 2000; Cruz et al., 2011). One important consequence of deforestation in the watershed is the silting up of lakes (Enea et al., 2012), including those at humid low-latitude areas (Cohen et al., 2005; Bakoariniaina et al., 2006). However, the lake is in a region relatively well protected, and therefore there is no other explanation other than deforestation in the margins to have caused the peak in OC burial around the 1950s. The riparian forest systems are generally effective in reducing the sediment transport by surface runoff, with the removal of this vegetation increasing the erosion processes, especially in the Amazon Basin as a result of intense rainfall (Neill et al., 2013). The peak in the significantly greater $\delta^{13} \mathrm{C}$ and lower $\delta^{15} \mathrm{~N}$ values coupled to higher OC burial rates were observed in the phase between $\sim 1930$ and 1970 in Jupindá Lake (one-way ANOVA followed by Tukey's post test, $p<0.05$; Fig. 7). The $\delta^{13} \mathrm{C}$ values were greater in the $\sim 1930$ to 1970 phase as related to those previous and after, respectively (one-way ANOVA followed by Tukey's post test, $p<0.05$ ). This peak between $\sim 1930$ and 1970 also showed $\delta^{15} \mathrm{~N}$ values lower and OC burial rates higher than other phases (one-way ANOVA followed by Tukey's post test, $p<0.05$ ).

We also found a spatial dependence of the carbon accumulation in Lake Jupindá, as the much lower OC burial was coupled to higher deforestation rates in those larger buffers around its margins and main fluvial channels $(500,1000$ and $6000 \mathrm{~m}$ ) in the period after the 1970s (between the 1970s to
$2010)$ than that before ( $\sim 1930$ to 1970$)$. This confirms previous evidence that the recent deforestation process in the region commenced in the riparian zone (Amorim, 2000; Cruz et al., 2011), and not in the interior of the forest. The enhanced OC burial in lacustrine sediments before $\sim 1970$ was related to higher deforestation rates only in the riparian vegetation zone (100 m buffers), suggesting a higher influence of deforestation with decreasing distance to water courses. Therefore, the soil carbon enrichment to the aquatic sediments during the peaks of riparian deforestation may cause intense but temporary carbon burial events in the Amazon floodplain, potentially representing only a significant part of the total loss of terrestrial organic matter. In addition, the continued removal of vegetation from the interior of the forest might not be directly related to increases in OC burial, even temporarily, in depositional aquatic ecosystems.

\section{Conclusions}

Palaeolimnological techniques were used with a historical spatial analysis of deforestation to interpret changes in sediment characteristics during the past century. The Pu dating method closely approximates measurements from the ${ }^{210} \mathrm{~Pb}$ chronologies and hence offers a technique to determine sedimentation rates and carbon accumulation in Amazon sediments. An increase in OC burial, up to $298 \mathrm{OC} \mathrm{g} \mathrm{m}^{-2} \mathrm{yr}^{-1}$, coincides with changes in the $\delta^{13} \mathrm{C}$ and $\delta^{15} \mathrm{~N}$ signatures, likely influenced by the heavy deforestation in riparian systems of this region during the 1940s and 1950s. It is suggested that the net increase in carbon burial towards the center of the sediment core, which represents the highest carbon burial rates during the 1950s, is a result of a change in source of organic matter deposition. However, any increase in OC burial rates attributed to deforestation might be lower than the loss of terrestrial biomass in the standing crop or soils. The differing carbon burial rates along the sediment core therefore identify the potential complexity of the Amazon floodplain lakes, directly related to the development within the Basin. This work supports the urgent need for management practices based on the conservation of riparian forests, demonstrating the spatial dependence of carbon burial capacity of the Amazon floodplain lakes with respect to advances in deforestation in the Basin.

Data availability. All information necessary to reproduce the results are included in the manuscript.

Competing interests. The authors declare that they have no conflict of interest.

Acknowledgements. Luciana M. Sanders is supported by APA and IPRS scholarships. Humberto Marotta and Alex Enrich-Prast 
received research grants from the Brazilian Research Council (CNPq - "Programa Universal" and "Bolsa de Produtividade") and the Research Support Foundation of the State of Rio de Janeiro (FAPERJ - "Programa Jovem Cientista do Nosso Estado"). Christian J. Sanders is supported by the Australian Research Council (DE160100443).

Edited by: Steven Bouillon

Reviewed by: Jack Hutchings and one anonymous referee

\section{References}

Aalto, R., Maurice-Bourgoin, L., Dunne, T., Montgomery, D. R., Nittrouer, C. A., and Guyot, J. L.: Episodic sediment accumulation on Amazonian flood plains influenced by El Niño/Southern Oscillation, Nature, 425, 493-497, 2003.

Abril, G., Martinez, J. M., Artigas, L. F., Moreira-Turcq, P., Benedetti, M. F., Vidal, L., Meziane, T., Kim, J. H., Bernardes, M. C., Savoye, N., Deborde, J., Souza, E. L., Albéric, P., Landim De Souza, M. F., and Roland, F.: Amazon River carbon dioxide outgassing fuelled by wetlands, Nature, 505, 395-398, 2014.

Amorim, A. T. d. S.: Santarém: uma síntese histórica, Canoas, Ulbra, Santarem, Brazil, 2000.

Anderson, N. J., Dietz, R. D., and Engstrom, D. R.: Land-use change, not climate, controls organic carbon burial in lakes, Proc. Biol. Sci., 280, 20131278, https://doi.org/10.1098/rspb.2013.1278, 2013.

Appleby, P. G. and Oldfield, F.: Application of lead-210 to sedimentation studies, in: Uranium Series Disequilibrium: Application to Earth, Marine and Environmental Science, edited by: Ivanovich, M. and Harmon, S., Oxford Science Publications, 731-783, 1992.

Bakoariniaina, L. N., Kusky, T., and Raharimahefa, T.: Disappearing Lake Alaotra: monitoring catastrophic erosion, waterway silting, and land degradation hazards in Madagascar using Landsat imagery, J. Afr. Earth Sci., 44, 241-252, 2006.

Brodie, C. R., Casford, J. S. L., Lloyd, J. M., Leng, M. J., Heaton, T., Kendrick, C. P., and Yongqiang, Z.: Evidence for bias in $\mathrm{C} / \mathrm{N}$, ${ }^{13} \mathrm{C}$ and $\delta^{15} \mathrm{~N}$ values of bulk organic matter, and on environmental interpretation, from a lake sedimentary sequence by preanalysis acid treatment methods, Quaternary Sci. Rev., 30, 30763087, 2011.

Cohen, A. S., Palacios-Fest, M. R., McGill, J., Swarzenski, P. W., Verschuren, D., Sinyinza, R., Songori, T., Kakagozo, B., Syampila, M., O'Reilly, C. M., and Alin, S. R.: Paleolimnological investigations of anthropogenic environmental change in Lake Tanganyika: I. An introduction to the project, J. Paleolimnol., 34, 1-18, 2005.

Cole, J. J., Prairie, Y. T., Caraco, N. F., McDowell, W. H., Tranvik, L. J., Striegl, R. G., Duarte, C. M., Kortelainen, P., Downing, J. A., Middelburg, J. J., and Melack, J.: Plumbing the global carbon cycle: integrating inland waters into the terrestrial carbon budget, Ecosystems, 10, 172-185, https://doi.org/10.1007/s10021006-9013-8, 2007.

Cruz, H., Sablayrolles, P., Kanashiro, M., Amaral, M., and Plinio, S.: Relação empresa/comunidade no manejo florestal comu- nitário e familiar: Uma contribuição do Projeto Floresta em pé, 2011.

Diaz, R. J. and Rosenberg, R.: Spreading dead zones and consequences for marine ecosystems, Science, 321, 926-929, 2008.

Dietz, R. D., Engstrom, D. R., and Anderson, N. J.: Patterns and drivers of change in organic carbon burial across a diverse landscape: insights from 116 Minnesota lakes, Global Biogeochem. Cy., 29, 708-727, 2015.

Dong, X., Anderson, N. J., Yang, X., Chen,X., and Shen, J.: Carbon burial by shallow lakes on the Yangtze floodplain and its relevance to regional carbon sequestration, Glob. Change Biol., 18, 2205-2217, 2012.

Downing, J. P., Meybeck, M., Orr, J. C., Twilley, R. R., and Scharpenseel, H. W.: Land and water interface zones, Water Air Soil Pollut., 70, 123-137, 1993.

Enea, A., Romanescu, G., and Stoleriu, C.: Quantitative Considerations Concerning the Source-Areas for the Silting of the Red Lake (Romania) Lacustrine Basin, Romania, 2012.

Fearnside, P. M.: Do hydroelectric dams mitigate global warming? The case of Brazil's Curuá-Una Dam, Mitig. Adapt. Strat. Gl., 10, 675-691, 2005.

Gordon, S. I.: Utilizing LANDSAT imagery to monitor land-use change: a case study in Ohio, Remote Sens. Environ., 9, 189196, 1980.

Goulding, M.: Flooded forests of the Amazon, Sci. Am., 268, 114$120+115,1993$.

Hoffmann, T., Schlummer, M., Notebaert, B., Verstraeten, G., and Korup, O.: Carbon burial in soil sediments from Holocene agricultural erosion, Central Europe. Global Biogeochem. Cy., 27, 828-835, 2013.

INPE: Program for the Estimation of Amazon Deforestation, available at: http://www.obt.inpe.br/prodes/prodes_1988_2015n.htm, last access: 20 November 2016.

Ivanovich, M. and Harmon, S.: Uranium Series Disequilibrium Applications to Earth, Marine and Environmental Sciences, 2nd edition, Oxford Science Publications, 1992.

Junk, W. J.: Current state of knowledge regarding South America wetlands and their future under global climate change, Aquat. Sci., 75, 113-131, 2013.

Kelley, J. M., Bond, L. A., and Beasley, T. M.: Global distribution of $\mathrm{Pu}$ isotopes and 237Np, Sci. Total Environ., 237/238, 483-500, https://doi.org/10.1016/S0048-9697(99)00160-00166, 1999.

Ketterer, M. E., Hafer, K. M., Jones, V. J., and Appleby, P. G.: Rapid dating of recent sediments in Loch Ness: inductively coupled plasma mass spectrometric measurements of global fallout plutonium, Sci. Total Environ., 322, 221-229, 2004.

Ligocki, L. P.: Comportamento Geotécnico da Barragem de CuruáUna, Pará, Rio de Janeiro, 2003.

Lucas, C. M., Schöngart, J., Sheikh, P., Wittmann, F., Piedade, M. T. F., and McGrath, D. G.: Effects of land-use and hydroperiod on aboveground biomass and productivity of secondary Amazonian floodplain forests, Forest Ecol. Manag., 319, 116-127, 2014.

Marotta, H., Bento, L., De Esteves, F. A., and Enrich-Prast, A.: Whole ecosystem evidence of eutrophication enhancement by wetland dredging in a shallow Tropical Lake, Estuar. Coast., 32, 654-660, 2009.

Marotta, H., Duarte, C. M., Meirelles-Pereira, F., Bento, L., Esteves, F. A., and Enrich-Prast, A.: Long-term $\mathrm{CO}_{2}$ variability in 
two shallow tropical lakes experiencing episodic eutrophication and acidification events, Ecosystems, 13, 382-392, 2010.

Marotta, H., Pinho, L., Gudasz, C., Bastviken, D., Tranvik, L. J., and Enrich-Prast, A.: Greenhouse gas production in low-latitude lake sediments responds strongly to warming, Nat. Clim. Change, 4, 467-470, 2014.

Melack, J. M., Hess, L. L., Gastil, M., Forsberg, B. R., Hamilton, S. K., Lima, I. B. T., and Novo, E. M. L. M.: Regionalization of methane emissions in the Amazon Basin with microwave remote sensing, Glob. Change Biol., 10, 530-544, 2004.

Munyati, C: Wetland change detection on the Kafue Flats, Zambia, by classification of a multitemporal remote sensing image dataset, Int. J. Remote Sens., 21, 1787-1806, 2000.

Naidu, A. S., Cooper, L. W., Finney, B. P., Macdonald, R. W., Alexander, C., and Semiletov, I. P.: Organic carbon isotope ratio $\left(\delta^{13} \mathrm{C}\right)$ of Arctic Amerasian Continental shelf sediments, Int. J. Earth Sci., 89, 522-532, 2000.

Neill, C., Coe, M. T., Riskin, S. H., Krusche, A. V., Elsenbeer, H., Macedo, M. N., McHorney, R., Lefebvre, P., Davidson, E. A., Scheffler, R., Silva Figueira, A. M., Porder, S., and Deegan, L. A.: Watershed responses to Amazon soya bean cropland expansion and intensification, Philos. T. R. Soc. B, 368, https://doi.org/10.1098/rstb.2012.0425, 2013.

Neue, H. U., Gaunt, J. L., Wang, Z. P., Becker-Heidmann, P., and Quijano, C.: Carbon in tropical wetlands, Geoderma, 79, 163$185,1997$.

Ometto, J. P. H. B., Ehleringer, J. R., Domingues, T. F., Berry, J. A., Ishida, F. Y., Mazzi, E., Higuchi, N., Flanagan, L. B., Nardoto, G. B., and Martinelli, L. A.: The stable carbon and nitrogen isotopic composition of vegetation in tropical forests of the Amazon Basin, Brazil, Biogeochemistry, 79, 251-274, 2006.

Peixoto, R. B., Marotta, H., Bastviken, D., and Enrich-Prast, A.: Floating aquatic macrophytes can substantially offset open water $\mathrm{CO}_{2}$ emissions from tropical floodplain lake ecosystems, Ecosystems, 19, 724-736, 2016.
Sanders, C. J., Eyre, B. D., Santos, I. R., MacHado, W., LuizSilva, W., Smoak, J. M., Breithaupt, J. L., Ketterer, M. E., Sanders, L., Marotta, H., and Silva-Filho, E.: Elevated rates of organic carbon, nitrogen, and phosphorus accumulation in a highly impacted mangrove wetland, Geophys. Res. Lett., 41, 24752480, 2014.

Sanders, C. J., Santos, I. R., Maher, D. T., Breithaupt, J. L., Smoak, J. M., Ketterer, M., Call, M., Sanders, L., and Eyre, B. D.: Examining ${ }^{239+240} \mathrm{Pu},{ }^{210} \mathrm{~Pb}$ and historical events to determine carbon, nitrogen and phosphorus burial in mangrove sediments of Moreton Bay, Australia, J. Environ. Radioactiv., 151, 623-629, 2016.

Sanders, L. M., Taffs, K. H., Stokes, D. J., Sanders, C. J., Smoak, J. M., Enrich-Prast, A., Macklin, P., Santos, I. R., and Marotta, H.: Carbon accumulation in Amazonian floodplain lakes: A significant component of Amazon budgets?, Limnol. Oceanogr. Lett., 2, 29-35, https://doi.org/10.1002/lol2.10034, 2017.

Skole, D. and Tucker, C.: Tropical deforestation and habitat fragmentation in the amazon: Satellite data from 1978 to 1988, Science, 260, 1905-1910, 1993.

Smith, L. K., Melack, J. M., and Hammond, D. E.: Carbon, nitrogen, and phosphorus content and ${ }^{210} \mathrm{~Pb}$-derived burial rates in sediments of an Amazon floodplain lake, Amazoniana, 17, 413436, 2002.

Stanley, E. H., Powers, S. M., Lottig, N. R., Buffam, I., and Crawford, J. T.: Contemporary changes in dissolved organic carbon (DOC) in human-dominated rivers: Is there a role for DOC management?, Freshwater Biol., 57, 26-42, 2012.

Zocatelli, R., Moreira-Turcq, P., Bernardes, M., Turcq, B., Cordeiro, R. C., Gogo, S., Disnar, J. R., and Boussafir, M.: Sedimentary evidence of soil organic matter input to the curuai amazonian floodplain, Org. Geochem., 63, 40-47, 2013. 